\title{
NEW SPECIES OF HAEMATOZOA FROM THE AVIAN FAMILIES CAMPEPHAGIDAE AND APODIDAE
}

BARRACLOUGH R.K.*, ROBERT V.** \& PEIRCE M.A. ${ }^{* * *, * * * *}$

\section{Summary:}

Leucocytozoon coracinae sp. nov. is described from the avian family Campephagidae and Hepatozoon apodis sp. nov. from the Apodidae. The distribution of these parasites within their respective families is discussed.

KEY WORDS : avian haematoza, Leucocytozoon, Hepatozoon, new species, hosts, distribution, Malaysia, Madagascar.

M ore than 200 named haemosporidians infecting birds are thought to be valid species (Valkiûnas, 2005). These are placed in three genera: Plasmodium, Haemoproteus and Leucocytozoon. Characters used to define these genera and species have included morphology using light and electron microscopy, the course and details of the life-cycle, and host taxonomy. In fact, it has been rare for a combination of all these characters to be employed and most of these species have been described using a subset of criteria. More precisely, descriptions have most frequently been made using the custom (more or less recognized as a rule) that any haemosporidians observed for the first time in a bird family can be considered as a new parasite species. Exceptions occur within the genus Plasmodium, but this practice, in combination with descriptions of morphological distinctiveness, is still considered an appropriate approach for Haemoproteus and Leucocytozoon. For instance, all the recent descriptions of the new species of the order Haemospororidia (Danilewsky, 1885), described from Malagasy birds, were based on arguments simply rela-

* Ecology \& Conservation Group, Institute of Natural Resources, Massey University, Albany Campus, Private Bag 102-904, NSMC, Auckland, New Zealand.

** Institut de Recherche pour le Développement UR 16, and Muséum National d'Histoire Naturelle USM-504, CP 52, 61, rue Buffon, 75231 Paris cedex 05, France.

***: MP International Consultancy, 6 Normandale House, Normandale, Bexhill-on-Sea, East Sussex TN39 3NZ, UK.

***** Corresponding Associate, International Reference Centre for Avian Haematozoa, Queensland Museum, South Brisbane, Queensland, Australia.

Correspondence: Vincent Robert

Tel.: 33 (0) 140793513 - Fax: 33 (0) 140793499.

E-mail: v.robert@mnhn.fr
Résumé : NOUVELleS ESPÈCeS D'HAEMATOZOAIRES DES FAMILLES D'oiseaux Campephagidae et APODIDAe

Leucocytozoon coracinae sp. nov. est décrit de la famille d'oiseaux Campephagidae, et Hepatozoon apodis sp. nov. de la famille Apodidae. La distribution de ces parasites au sein de leurs familles respectives est discutée.

MOTS CLÉS : hématozaires d'oiseaux, Leucocytozoon, Hepatozoon, nouvelles espèces, hôtes, distribution, Malaisie, Madagascar.

ted to: $i$ ) classical morphology of parasites blood stages observed in thin-smears by light microscopy, and ii) family of bird host (Savage, 2004; Savage \& Greiner, 2004, 2005; Savage et al., 2004, 2005, 2006).

New insights are being gained from the rapidly increasing volume of DNA sequencing work which provides genetic information such as cytochrome $b$ gene sequences for classically named parasites. The question of how this new information reinforces or refutes the old taxonomic order is the focus of current stimulating research (Fallon et al., 2003, 2005; Martinsen et al., 2006; Krizanauskiene et al., 2006; Hellgren et al., 2007). It is impossible to predict the ultimate conclusions, yet some trends are emerging. Firstly, the classical morphology is generally reinforced; for example even slight character differences such as the shape of hemozoin crystals do differentiate $P$. cathemerium and P. relictum (Laird, 1998; Noland et al., 2003). Secondly, the distribution of parasite species across hosts is often differentiated at taxonomic level lower or equal to host family (Martinsen et al., 2006; Hellgren et al., 2007). Although instances of intra-order, but inter-family hostswitching by Haemoproteus has been observed (e.g. Bensch et al., 2000; Ricklefs et al., 2005). Thirdly, morphology alone underestimates the total biodiversity because, by definition, it is unable to distinguish cryptic species. The number of such species cannot currently be precisely estimated, but it has been speculated that there may be as many parasite taxa of Plasmodium and Haemoproteus as bird species (Bensch et al., 2004). This trend for increased parasite diversity revealed through sequencing is also emerging in Leucocytozoon (Hellgren, 2005; Sehgal et al., 2006). Consequently, it seams reasonable to continue to nominate new Leu- 
cocytozoon species on the classical basis for the genus, which does not necessarily incorporate genetic or phylogenetic information.

The genus Hepatozoon follows the same pattern for taxonomic status of various species. Thereby the majority of species have been described solely on the appearance of gametocytes within the blood cells of their vertebrate hosts, usually leucocytes in birds. Moreover, description of the 15 species of Hepatozoon parasitising birds, that are considered as valid (Peirce, 2005), have been exclusively based on morphological measurements of parasites in blood cells as well as their assumed host family specificity, since the life cycles for each of these species are unknown. Molecular studies of this genus remain rare, but Merino et al. (2006) revealed that molecular characterization of the $18 \mathrm{~S}$ rDNA gene of an avian parasite microscopically identified as Hepatozoon was in fact closely related to Lankesterella. This finding implies that confusion is possible using light microscopy between gametocytes of Hepatozoon in a leucocyte versus lankesterellid sporozoites in an erythrocyte. Such a conclusion is extremely surprising and, for us, requires further confirmation before we disregard the recommendation that Smith made in his well-argued review (1996), to include all the haemogregarine infections in birds within the genus Hepatozoon.

In a recent review of avian haematozoan parasites it was noted that the only species described from the Campephagidae (cuckoo-shrikes), Haemoproteus tephrodornis de Mello, 1935 was a species requiring a taxonomic review and redescription (Peirce, 2005). Blood smears from birds of this family deposited in the collection of the International Reference Centre for Avian Haematozoa (IRCAH) failed to provide adequate material although a hitherto undescribed species of Leucocytozoon Berestneff, 1904 was observed in a number of slides. A recent survey of birds in Madagascar included three Madagascar cuckoo-shrikes Coracina c. cinerea (Muller), which although not containing any haemoproteid parasites, did show a low parasitaemia with a Leucocytozoon sp. From the same survey in Madagascar a single specimen of the Madagascan black swift Apus barbatus balstoni (Bartlett) showed infection with a species of Hepatozoon, not previously recorded from Apodidae. The descriptions of these two new species are presented here.

\section{MATERIALS AND METHODS}

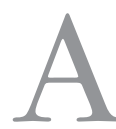

11 stained blood smears (most with Giemsa) from Campephagidae deposited in the IRCAH collection together with more recent (Giemsa stained) material from Madagascar were screened for the presence of Leucocytozoon. Additionally slides from Apodidae from Madagascar were also screened. The samples from Madagascar were all collected from Forêt d'Ambohitantely NE of Ankazobe, 18 10' 17" S, $47^{\circ} 16^{\prime} 55^{\prime \prime} \mathrm{E}, 1,620 \mathrm{~m}$ a.s.l.

Morphometric parameters were obtained employing the methods established by Bennett et al. (1991, 1992). Leucocytozoon gametocytes frequently exhibited a distorted morphology as often encountered in blood smears as a result of smear preparation. Only undistorted parasites were used in obtaining measurements. All images were captured using a Nikon Coolpix 4500 digital camera attached to Zeiss binocular microscope.

\section{RESULTS}

$\mathrm{H}$ itherto undescribed species of Leucocytozoon and Hepatozoon were observed from birds of the Campephagidae and Apodidae respectively. Descriptions of these new species are presented here.

FAMILY CAMPEPHAGIDAE (CUCKOO-SHRIKES)

PARASITE: LEUCOCYTOZOON CORACINAE SP. NOV. (Fig. 1A-F)

- Type host: Coracina novaehollandiae (Gmelin). - Type locality: Mount Brinchang, Pahang State, Malaysia.

- Vector: unknown but presumed to be a species of simuliid.

. Etymology: named for the host genus.

- Immature gametocyte. Merozoites usually invade leucocytes, most commonly lymphocytes. Developing gametocytes (Fig. 1A-B) cause indentation of the host cell nucleus and this becomes stretched around the periphery of the parasite as it matures.

- Macrogametocyte (Fig. 1C-D; Table I)

Mature parasites present the usual sexual differentiating characteristics. Parasite small occupying about $66 \%$ of area of the host cell-parasite complex, round or slightly ovoid: parasite nucleus round to ovoid with marked karyosome, occupying $8 \%$ of area of parasite; nucleus of host cell-parasite complex extends as band around parasite with occasional thicker areas on either end, covering $55-60 \%$ of the periphery of the parasite and occupying $34 \%$ of area of host cell-complex.

. Microgametocyte (Fig. 1E-F; Table I)

Morphologically similar to macrogametocyte, but averaging about $9 \%$ more in size. Nucleus is dispersed; karyosome occasionally seen. Nucleus of host cell-parasite complex extends as a band around the parasite periphery occupying a similar area as in macrogametocytes. Ratio of macrogametocytes to microgametocytes is $2: 1$. 

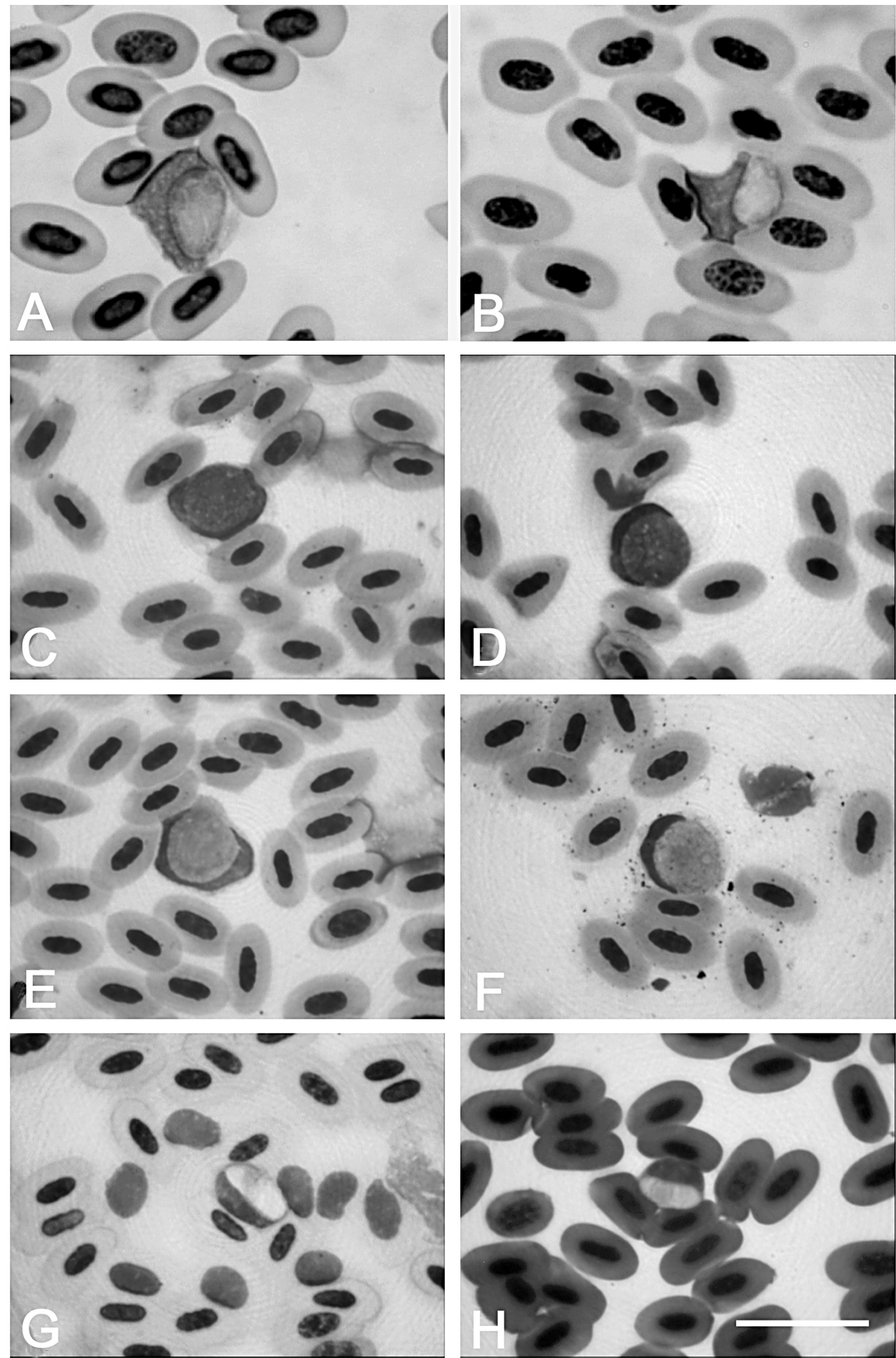

Fig. 1. - (A-F) Leucocytozoon coracinae sp. nov.: (A-B) immature gametocytes; (C-D) macrogametocytes; (E) almost mature microgametocyte; (F) mature microgametocyte. $-(\mathrm{G}-\mathrm{H})$ Hepatozoon apodis sp. nov.: mature gametocytes. Scale bar $=16 \mu \mathrm{m}(\mathrm{A}-\mathrm{B}),=20 \mu \mathrm{m}(\mathrm{C}-\mathrm{H})$. 


\begin{tabular}{|c|c|c|c|c|c|c|c|c|c|}
\hline & & \multicolumn{4}{|c|}{$\begin{array}{l}\text { Macrogametocytes } \\
\qquad(\mathrm{n}=25)\end{array}$} & \multicolumn{4}{|c|}{$\begin{array}{l}\text { Microgametocytes } \\
\quad(\mathrm{n}=25)\end{array}$} \\
\hline & & Mean & SD & Min & $\operatorname{Max}$ & Mean & $\mathrm{SD}$ & Min & Max \\
\hline \multirow[t]{4}{*}{ Parasite } & Max. diameter & 10.3 & 0.8 & 9.0 & 12.2 & 10.8 & 1.0 & 9.6 & 12.3 \\
\hline & Min. diameter & 9.4 & 0.4 & 8.8 & 10.7 & 9.0 & 0.9 & 6.1 & 11.0 \\
\hline & Periphery of parasite & 31.2 & 1.2 & 28.1 & 34.9 & 31.1 & 2.2 & 28.3 & 35.8 \\
\hline & Area of parasite & 75.7 & 10.3 & 62.9 & 96.7 & 81.4 & 15.2 & 64.3 & 102.0 \\
\hline \multirow[t]{3}{*}{ Parasite nucleus } & Max. diameter & 3.7 & 0.7 & 2.9 & 4.8 & & & & \\
\hline & Min. diameter & 2.3 & 0.4 & 1.6 & 2.9 & & & & \\
\hline & Nucleus area & 6.7 & 1.5 & 4.8 & 9.8 & & & & \\
\hline \multirow[t]{3}{*}{ Host-parasite complex } & Max. length & 12.9 & 1.1 & 11.0 & 14.6 & 12.0 & 0.8 & 11.1 & 13.9 \\
\hline & Min. length/diameter & 11.2 & 0.7 & 9.3 & 13.1 & 10.7 & 1.1 & 8.2 & 12.3 \\
\hline & Complex area & 114.1 & 14.2 & 95.0 & 144.1 & 106.5 & 16.1 & 88.2 & 131.6 \\
\hline
\end{tabular}

Table I. - Morphometric parameters (in $\mu \mathrm{m}$ and $\mu \mathrm{m}^{2}$ ) of gametocytes of Leucocytozoon coracinae sp. nov. ( $\mathrm{n}=\mathrm{sample}$ size).

Hapantotype: IRCAH: G401061 from C. novaehollandiae coll. Laird, 30 September 1959, Mt Brinchang, Malaysia. Parahapantotypes: IRCAH: G405148 from Tephrodornis virgatus (Temminck) coll. McClure, 18 December 1964, Chieng-mai, Thailand; Protozoology collection 27ZS, Muséum National d'Histoire Naturelle (MNHN), Paris from Coracina cinerea (Muller) coll. Barraclough, 16 February 2004, Forêt d'Ambohitantely, Ankazobe Tampoketsa, Madagascar.

- Other hosts. Lalage nigra (Forster).

\section{Comments}

Leucocytozoon coracinae is a typically small round morph currently known only from south-east Asia and Madagascar, but presumably occurs throughout the range of the Campephagidae.

\section{FAMILY APODIDAE (SWIFTS) \\ PARASITE: HEPATOZOON APODIS SP. NOV.} (Fig. 1G-H)

- Type host: Apus barbatus balstoni (Bartlett).

- Type locality: Forêt d'Ambohitantely, Ankazobe Tampoketsa, Madagascar.

- Vector: unknown.

- Etymology: named from the host family.

.Description of parasite (Fig. 1G-H; Table II)

Gametocytes are associated with small monocytes which are not hypertrophied; host cell cytoplasm rarely seen; parasite lying along side host cell nucleus. Gameto-

\begin{tabular}{llrrrr}
\hline & & Mean & SD & Min. & Max. \\
\hline Parasite & Length & 8.9 & 0.9 & 7.8 & 9.9 \\
& Width & 4.0 & 0.5 & 3.4 & 4.6 \\
& Area of parasite & 28.1 & 5.2 & 21.7 & 33.8 \\
\hline \multirow{2}{*}{ Vacuole } & Diameter & 2.5 & 0.4 & 1.9 & 2.9 \\
& Area of vacuole & 4.9 & 1.3 & 2.3 & 6.7 \\
\hline
\end{tabular}

Table II. - Morphometric parameters (in $\mu \mathrm{m}$ and $\mu \mathrm{m}^{2}$ ) of gametocytes of Hepatozoon apodis sp. nov. $(\mathrm{n}=25)$. cytes small, generally rod-shaped, with rounded ends, broadly ovoid. Of the 43 parasites seen the band shaped nucleus was only visible in four and therefore not possible to obtain morphometric parameters. Distinct parasite vacuole present; round to ovoid, staining greygreen, occupying $17 \%$ of the area of the parasite.

Hapantotype: IRCAH: G464969 from A. barbatus balstoni coll. Barraclough, 9 February 2004, Forêt d'Ambohitantely, Ankazobe Tampoketsa, Madagascar deposited in the IRCAH collection, Queensland Museum, South Brisbane, Queensland, Australia. Parahapantotype: Protozoology collection 26ZS, Muséum National d'Histoire Naturelle (MNHN), Paris from A. barbatus balstoni (duplicate slide) coll. Barraclough, 9 February 2004, Forêt d'Ambohitantely, Ankazobe Tampoketsa, Madagascar.

Comments

Hepatozoon apodis is currently known only from a single host, but presumably occurs throughout the range of the Apodidae which occupy all faunal regions.

\section{DISCUSSION}

W ith exceptions among a few closely related small passerine families, most avian haematozoa (except Plasmodium) are host family and sub-family specific (Peirce, 2005). Further advances in molecular techniques may change this view, but on current knowledge there is no reason to doubt the validity of the new species described here. Leucocytozoon coracinae sp. nov. is a typical small species with only round morphs occurring. It is smaller than L. majoris, also distributed in avian Malagasy birds (Savage et al., in press). Furthermore the nucleus of host cell-parasite complex occupies some $55-60 \%$ of the periphery of the parasite compared to $80 \%$ with L. majoris. In fact $L$ coracinae looks more like $L$. sakharoffi from Corvidae but the distinction between family hosts is evi- 
dent. The Campephagidae contains some 72 species widely distributed throughout most faunal regions with the exception of the Americas and it is reasonable to assume the parasite occurs within the range of the Campephagidae, with most of these species being susceptible to infection. Nothing is known regarding pathogenicity or morbidity, but the parasite is most likely benign. As with the majority of leucocytozoids the vector is almost certainly a simuliid.

The low coloration in the Hepatozoon from the Apus was due to the degree of fixation and stain. The parasite vacuole visible in Fig. 1G-H (difficult to stain well) is a common feature of most avian Hepatozoon spp. (Bennett et al., 1992). Few species of Hepatozoon have been described in birds and H. apodis brings this total to 16. This is the first description of Hepatozoon in the order Apodiformes. Although currently described from a single host species the distribution is probably throughout the range of the Apodidae which occur in all faunal regions. Swifts are not commonly included in surveys of birds examined for haematozoa, so a lack of records is not surprising.

\section{ACKNOWLEDGEMENTS}

W e are grateful to Dr Mal Bryant of the Queensland Museum for the loan of material from the IRCAH collection. The Malagasy research (RKB and VR) was supported by the Institut de Recherche pour le Développement and by Groupe de Recherche sur le Paludisme of Institut Pasteur de Madagascar. Attale Ravaoarimalala assisted with the fieldwork.

\section{REFERENCES}

Bennett G.F., Earlé R.A. \& Peirce M.A. New species of avian Hepatozoon (Apicomplexa: Haemogregarinidae) and a redescription of Hepatozoon neophrontis (Todd and Wolbach, 1912) Wenyon, 1926. Systematic Parasitology, 1992, 23, 183-193.

Bennett G.F., Earlé R.A., Peirce M.A., Huchzermeyer F.W. \& Squires-Parsons D. Avian Leucocytozoidae: the leucocytozoids of the Phasianidae sensu lato. Journal of Natural History, 1991, 25, 1407-1428.

Bensch S., Stjernman M., Hasselquist D., Ostman O., Hansson B., Westerdahl H. \& Pinheiro R.T. Host specificity in avian blood parasites: a study of Plasmodium and Haemoproteus mitochondrial DNA amplified from birds. Proceedings of the Royal Society of London Series B-Biological Sciences, 2000, 267, 1583-1589.

Bensch S., Pérez-Tris J., Waldenström J. \& Hellgren O. Linkage between nuclear and mitochondrial DNA sequences in avian malaria parasites: multiple cases of cryptic speciation? Evolution, 2004, 58, 1617-1621.
Fallon S.M., Ricklefs R.E., Swanson B.L. \& Bermingham E. Detecting avian malaria: an improved polymerase chain reaction diagnostic. Journal of Parasitology, 2003, 89, 1044-1047.

Fallon S.M., Bermingham E. \& Ricklefs R.E. Host specialization and geographic localization of avian malaria parasites: a regional analysis in the Lesser Antilles. The American Naturalist, 2005, 165, 466-480.

HeLlgREN O. The occurrence of haemosporidian parasites in the Fennoscandian bluethroat (Luscinia svecica) population. Journal of Ornithology, 2005, 146, 55-60.

Hellgren O., Krizanauskiene A., Valkiûnas G. \& Bensch S. Diversity and phylogeny of mitochondrial cytochrome B lineages from six morphospecies of avian Haemoproteus (Haemosporida: Haemoproteidae). Journal of Parasitology, 2007, 93, 889-896.

Krizanauskiene A., Hellgren O., Kosarev V., Sokolov V., Bensch S. \& VAlKî̂NAS G. Variation in host specificity between species of avian hemosporidian parasites: evidence from parasite morphology and cytochrome B gene sequences. Journal of Parasitology, 2006, 92, 1319-1324.

LAIRD M. Avian Malaria in the Asian Tropical Subregion. Singapore: Springer, 1998, $130 \mathrm{p}$.

Martinsen E.S., PAPERna I. \& SChall J.J. Morphological versus molecular identification of avian Haemosporidia: an exploration of three species concepts. Parasitology, 2006, 133, 279-288.

Merino S., Martinez J., Martinez-de la Puente J., Criado-Fornelio A., Tomas G., Morales J., Lobato E. \& Garcia-Fraile S. Molecular chracterization of the 18S rDNA gene of the avian Hepatozoon reveals that it is closely related to Lankesterella. Journal of Parasitology, 2006, 92, 1330-1335.

Noland G.S., Briones N. \& Sullivan D.J. The shape and size of hemozoin crystals distinguishes diverse Plasmodium species. Molecular and Biochemical Parasitology, 2003, 130, 91-99.

PeIRCE M.A. A checklist of the valid avian species of Babesia (Apicomplexa: Piroplasmorida), Haemoproteus, Leucocytozoon (Apicomplexa: Haemosporida), and Hepatozoon (Apicomplexa: Haemogregarinidae). Journal of Natural History, 2005, 39, 3621-3632.

Ricklefs R.E., Swanson B.L., Fallon S.M., MartíneX-Abraín A., Scheuerlein A., Gray J. \& Latta S.C. Community relationships of avian malaria parasites in southern Missouri. ECOlogical Monographs, 2005, 75, 543-559.

SAvage A.F. Hematozoa of the avian family Philepittidae (the Asities and Sunbird Asities). Journal of Parasitology, 2004, 90, 1473-1474.

Savage A.F., Ariey F. \& Greiner E.C. Hematozoa of the avian family Vangidae (the Vangas). Journal of Parasitology, 2004, 90, 1475-1479.

Savage A.F., Ariey F. \& Greiner E.C. A new species of Plasmodium from Malagasy Vangas. Journal of Parasitology, 2005, 91, 926-930.

Savage A.F., Ariey F. \& Greiner E.C. Leucocytozoon atkinsoni n. sp. (Apicomplexa: Leucocytozoidae) from the avian family Timaliidae. Systematic Parasitology, 2006, 64, 105109. 
SAvage A.F. \& GeINER E.C. Hematozoa of the avian family Brachypteracidae (the Ground-Rollers). Journal of Parasitology, 2004, 90, 1468-1472.

Savage A.F. \& Geiner E.C. Haemoproteids of the avian family Dicruridae (the Drongos). Journal of Parasitology, 2005, 91, 131-134.

Sehgal R.N., Hull A.C., Anderson N.L., Valkiûnas G., MarKovets M.J., Kawamura S. \& Tell L.A. Evidence for cryptic speciation of Leucocytozoon spp. (Haemosporida, Leucocytozoidae) in diurnal raptors. Journal of Parasitology, 2006, 92, 375-379.

Sмiтн T.G. The genus Hepatozoon (Apicomplexa: Adeleina). Journal of Parasitology, 1996, 82, 565-585.

VAlkiÛNAS G. Avian malaria parasites and other Haemosporidia. Boca Raton: CRC Press, 2005, 932 p.

Reçu le 17 septembre 2007 Accepté le 9 janvier 2008 